\title{
"Limites y espejo": Linguistic Self-Consciousness in the Poetry of Vicente Aleixandre
}

\author{
\& \\ Jonathan Mayhew
}

The image of Vicente Aleixandre as a relatively unsophisticated creator has been remarkably tenacious. No one has called into question his mastery of language. The stylistic analyses of Carlos Bousoño, the author of the first and most influential monograph on the poet, have provided ample demonstration of the subtlety and power of his poetic technique. Still, few studies of his poetry have emphasized his linguistic self-consciousness, his awareness of the verbal medium as a theoretical problem. ${ }^{1}$ In a recent study, Philip Silver has given voice to the widespread view that Aleixandre is essentially naive as a poetic thinker. For Silver, the author of La destrucción o el amor typifies the Hispanic poet who, like Antaeus in Greek mythology, derives all of his strength from his ties to the earth (La casa de Anteo 48-156). Aleixandre would thus lack the theoretical self-consciousness that is essential to the modern poet. $^{2}$

1 There are several significant exceptions. The most complete treatment of Aleixandre's poetics is Puccini "Modalidades y desarrollos internos de la poética aleixandrina" (148-191). The title of Pope's essay - "Vicente Aleixandre y las limitaciones del lenguaje"-is deceptive, since he says very little about Aleixandre's linguistic self-consciousness. See also note 4 .

2 Silver's book is a landmark in its application of a modern theoretics to Hispanic poetry. The critic considers the task of studying this poetry in the context of a wider, more international tradition to be a crucial one. Unfortunately, however, his criterion is rather narrowly defined. In his view, modern poets are successful in their theoretical endeavors to the extent that they approach the poetics of Hölderlin, as interpreted by Paul de Man. 
This assessment, I would argue, makes the poet a victim of his own rhetoric. Many of Aleixandre's statements about his own work give the initial impression of a resolutely antitheoretical mind, more concerned with the content of his poetic vision than with language per se. In a statement of his poetics written in the 1930s for Gerardo Diego's anthology, for example, he protests against what he perceives to be a widespread tendency in modern poetry to exalt language for its own sake: "Frente a la divinizacíón de la palabra, frente a esa casi obscena delectación de la maestria o dominio verbal del artífice que trabaja la talla, confundiendo el destello del vidrio entre sus manos con la profunda luz creadora, hay que afirmir, hay que exclamar con verdad. No, la poesía no es cuestión de palabras" (Obras Completas II: 645; emphasis in original).

Aleixandre appears to be exalting the content of the poet's vision at the expense of a concern for the verbal medium in itself. He rejects the notion that the poet is primarily a wordsmith, refining language into a more perfect medium for the expression of thought. ${ }^{3}$ It could be argued, however, that Aleixandre's apparent denial of the linguistic nature of poetry reveals an obsession with language. His very distrust of words obliges him to consider the question of language in a way that a more obviously logophilic poet would not. I would argue that his attitude of suspicion is more characteristic of the modern poet than is the simple exaltation of poetic language. Aleixandre's poetry is indeed a "question of words," in the sense that it is both a quest for expression and a questioning of language. In his profession of the primacy of experience over words, Aleixandre aligns himself with one of the central currents of poetry since romanticism, the tradition that views language as an inherently defective system of signs that must continually be destroyed and recreated. Octavio Paz has succinctly summarized this attitude toward language in terms of a double imperative: "a un tiempo, destrucción y creación del lenguaje. Destrucción de las palabras y de los significados, reino del silencio; pero, igualmente, palabra en busca de la Palabra" (7).

While adamantly denying that it is a "cuestión de palabras," Aleixandre concludes his "poética" by defining poetry in terms of its relation to language. He dismisses everyday words as "estrechos

${ }^{3}$ As Puccini has pointed out, the target of these remarks is probably Juan Ramón Jiménez (157-160). 
moldes previos" or "signos insuficientes," from which the "genio poético" must escape:

... fuga o destino hacia un generoso reino, plenitud o realidad soberana, realidad suprasensible, mundo incierto donde el enigma de la poesía está atravesado por las supremas categorías, últimas potencias que iluminan y signan la oscura revelación para la que las palabras trastornen su consuetudinario sentido.

Although the poet emphasizes the reality that lies beyond ordinary perception and ordinary language, this marvelous realm can be reached only through a specifically verbal act: the subversion of the accepted usage of words. This disturbance of sense implies the creation of a new and paradoxical poetic speech, one that will somehow correspond to the dark revelation, the paradoxically opaque unveiling, of poetic vision.

It has been customary to divide Aleixandre's poetic production into three major periods: the early Surrealist-influenced poetry, the "realist" tendency of the post-war period, and the metaphysical investigations of Poemas de la consumación (1968) and Diálogos del conocimiento (1974). Aleixandre's self-consciousness is most evident at the beginning and at the end of his long career. In many poems written during the 1930s, the poet expresses his view of language in terms very similar to those he employs in his poética. Words in their ordinary state impede the poet's expression of his vision, or even his access to it. In a frequently quoted poem from Espadas como labios (1932), "Palabras," the speaker views language in essentially negative terms:

Pero no importa que todo esté tranquilo

(La palabra esa lana marchita)

Flor tú muchacha casi desnuda viva viva

(la palabra esa arena machacada) (Espadas como labios 85$)^{4}$

${ }^{4}$ I cite Cano's critical edition, instead of the Obras completas, since it reproduces the lack of punctuation found in the original, 1932 edition. Other critics have recognized the metapoetic dimension of Espadas como labios. "Puede afirmarse sin ambages que se trata de una poesia del lenguaje en sus relaciones con el pensamiento que a veces llega a la temática del metalenguaje" (Villanova 125). "La cosmovisión aleixandrina - sin discusión, al menos, la del 'primer Aleixandre'-se sustenta, trabadamente, indisolublemente, en el lenguaje. Ya que su universo, por ser de ideas o de sensaciones, no es espejo de realidad sea cual sea la deformación o floritura del vidrio, sino espejo de lenguaje" (Villena 8). 
Once again, this denigration of words must be understood as part of a dialectical movement. Language is an obstacle to expression, but a necessary one, for without its interference or resistance there would be no tension between the words of the poem and the reality that they attempt to capture.

It could be argued that it is the tension between the poet's vision and its linguistic expression, rather than content of his vision per se, that most preoccupies the early Aleixandre. Paul Ilie, for example, has convincingly interpreted Pasion de la tierra as an allegory of the poet's anxiety about his poetic gift. The opening poem of Espadas como labios, entitled "Mi voz," calls into question virtually every aspect of the communicative situation:

He nacido una noche de verano entre dos pausas Háblame te escucho

He nacido Si vieras qué agonía representa la luna sin esfuerzo

He nacido Tu nombre era la dicha Bajo un fulgor una esperanza un ave Llegar llegar El mar era un latido el hueco de una mano una medalla tibia Entonces son posibles ya las luces las caricias la piel el horizonte ese decir palabras sin sentido que ruedan como oídos caracoles como un lóbulo abierto que amanece (escucha escucha) entra la luz pisada (Espadas como labios 45)

In: his famous "Closing Statement on Linguistics and Poetics," Roman Jakobson posited a model of communication consisting of six elements: addressor, addressee, contact, code, message, and context. According to Jakobson, different kinds of utterances privilege one or another of six functions. In Aleixandre's text, on the other hand, none of these elements is fully functional. The lyric speaker and his addressee - two isolated and vaguely defined personages - seem unable to establish contact with each other. Nor do they share any meaningful code, striving only to "decir palabras sin sentido." As in much modern poetry, the referential function (for Jakobson, a focus on the context of utterance) is extremely weak. Of course, the text constitutes a "poetic" use of language, in that it focuses on the message for its own sake. Yet, because of the weakness of the other five elements, this poetic function has the effect of undermining rather than contributing to the act of communication. 
It is interesting to note that Aleixandre's critics have tended to privilege La destrucción o el amor, which contains fewer explicitly self-conscious poems, over Pasión de la tierra and Espadas como labios, his two earlier Surrealist works. The poetic voice heard in this volume appears to be more confident of its communicative power, as Aleixandre develops a more powerful but also more predictable set of rhetorical devices. The resulting confidence in language ultimately leads, in Aleixandre's second period, to a very different kind of metapoetry. Words continue to be perceived as obstacles to the attainment of poetic vision. The most significant novelty in the books written during the $40 \mathrm{~s}$ and $50 \mathrm{~s}$, however, is that this linguistic interference is much more easily displaced. A relative clarity of expression replaces the tortured struggle with language characteristic of the earlier poetry. In a passage notable for its magnificent rhetoric, the speaker of "El poeta," the initial poem in Sombra del paraiso (1944), instructs the poet who is about to read the book to throw it down, to reject it as an inadequate representation of the vitality of nature:

$\mathrm{Si}$, poeta, arroja este libro que pretende encerrar en sus páginas un destello del sol,

y mira a la luz cara a cara, apoyada la cabeza en la roca, mientras tus pies remotísimos sienten el beso postrero del poniente y tus manos alzadas tocan dulce la luna, y tu cabellera colgante deja estela en los astros. (Obras completas I: 484)

The obvious paradox here is that these words do not have the effect of prompting the lyric addressee (or the real reader for that matter) to stop reading the book. The result is likely to be the exact opposite: the speaker's words create the illusion that the book in question is not really a text at all, but an unmediated encounter with the naked elements of Aleixandre's paradise. ${ }^{5}$ This passage contains an implicit message to its readers instructing them to ignore the linguistic medium of poetry, to look through language as though it were a transparent glass that allowed them to come face to face with the light of the poet's transcendent vision.

The books that follow Sombra del paraiso continue to elide the question of language. In Historia del corazón (1954) and En un vasto

\footnotetext{
${ }^{5}$ Sylvia Sherno has studied a similar paradox in her discussion of Blas de Otero's Esto no es un libro, a book whose title comes from Leaves of Grass. Another post-war poet to make use of this topos is Gloria Fuertes. Whitman is a strong presence in Aleixandre's middle period.
} 
dominio (1962) Aleixandre no longer rejects everyday language as an impediment to a transcendent poetic vision. Rather, he accepts this language as an umproblematic channel of communication. Reading these books, one no longer senses any tension between language and its referents. The poet's lack of interest in the problem of poetic language corresponds to his desire to reach the largest possible audience. In the manifesto-like poem that opens En un vasto dominio. “'Para quién escribo?” (I: 797-9), the speaker affirms that his goal is to give voice to the concerns of those who cannot speak. For such a poetics, diametrically opposed to that of Espadas como labios, language is no longer a problem or even a question. It becomes a mere tool for the expression of meaning. If the poet is not a goldsmith he is at least a blacksmith. What the Aleixandre of these years shares with the poet who conceives of his craft as fine metalwork is a certain complacency about the capacity of language to obey his will, to represent his vision of reality unproblematically.

In the final phase of his career Aleixandre returns to a more complex vision of language, one which is reminiscent in many ways of his earlier poetics. Aleixandre's renewed interest in metapoetry corresponded to a widespread awakening of self-consciousness in Spanish poetry of the sixties and seventies. Led by young poets such as Guillermo Carnero and Pere Gimferrer, poets of all generations and tendencies began to call language into question with renewed fervor. It is no coincidence that Aleixandre was one of the major sponsors of these younger poets, and that Carnero and Gimferrer have both written intelligently and sympathetically about Aleixandre's later work.

Poemas de la consumación, like Espadas como labios, Sombra del paraiso and En un vasto dominio, begins with a statement of poetics. "Las palabras del poeta," however, is a much more elusive text than either "El poeta," or "El poeta canta por todos." 6 The poetfigure here is neither the vital, Whitmanesque singer of the former poem nor the Great Communicator of the latter. He is instead an old man whose words begin to fail him in the face of his impending end. At this point in the poet's career the mediation of words cannot be side-stepped: words are no longer direct repre-

\footnotetext{
${ }^{6}$ Myriam Najt's article "La palabra 'palabra' en 'Las palabras del poeta' " is, unfortunately, too narrow in its scope to live up to the promise of its title.
} 
sentations of an available reality, as in Aleixandre's "realist" phase, but a medium for the preservation of memory:

Después de la palabras muertas, de las aún pronunciadas o dichas, ¿qué esperas? Unas hojas volantes, más papeles dispersos. ¿Quién sabe? Unas palabras deshechas, como el eco o la luz que muere allá en gran noche.

This poem sets forward in discursive terms the implicit poetics of Poemas de la consumación. Language is no longer a transparent medium that can bring the poet and his readers into direct contact with a poetic vision of reality. Instead, it is an echo, a belated representation. As in both Aleixandre's early and middle periods, there is an implicit opposition between language and vitality. Here, however, the poet no longer has any access to this vitality outside of language. As a consequence, language is paradoxically identified with as well as opposed to life: "Morir es olvidar unas palabras."

While only a half-dozen poems after "Las palabras del poeta" explicitly address the linguistic theme, virtually all the poems in the volume touch upon it in some way. The structure of Poemas de la consumación allows a metapoetic reading of many poems that otherwise might not lend themselves to this approach. As with all of his books of poetry, with the exception of a few anthologies and miscellanies, Aleixandre has conceived the volume as an interdependent group of closely related poems, rather than a mere agglomeration of lyric poems. If anything, the book is even more tightly knit than the poet's previous efforts. For Gimferrer, Aleixandre's later poetry is "un arte combinatorio que procede por permutación, substitución o superposición de un repertorio muy parco de elementos" (273). Gimferrer goes on to make the surprising affirmation that the reiterative and paradigmatic structure of these books is imperceptible to the common reader, emerging only from the critic's analysis. I would argue, on the contrary, that this distinction is arbitrary, and that an awareness of the "permutation, substitution and superposition" of terms is an indispensable part of any reader's experience of the text. It is only by comparing and contrasting individual poems that one constructs a paradigm 
and thus makes sense of the larger whole. (It is possible, though, that the "common reader" is a mere fiction in this case, given the small audience for poetry and the difficulty of Aleixandre's final works.)

Since terms that relate to language specifically and to representation in general have a crucial place within the densely woven semantic web of the book, it is not necessary or even desirable to concentrate exclusively on the poet's more explicit statements of poetics. I would begin charting the semantic system of Poemas de la consumación with the key word palabra, which relates directly to other types of signs-signos, emblemas, nombres, textos-and to words that refer literally or metaphorically to poetry: poeta, palabra, canción. Palabra is also linked to words pertaining to orality: voz, boca, beso, lengua, labios. A line such as "roja pulpa besada que pronuncian" (II: 73) conflates the speech-act and the kiss, so that the word becomes an explicitly erotic act. There is another set of terms having to do with sound: son, sonido, eco, silencio, callar. Moving in another direction, language is linked metaphorically to other belated representations of reality: eco, espejo, imagen, reflejo, copia, sombra, huella, repetir. The imperfection of linguistic representation finds expression in words such as engaño, máscara, mentira, verdad, sueño. These terms lead us directly to the problem of knowledge that Guillermo Carnero has studied in Aleixandre's later work. ${ }^{7}$ This epistemological preoccupation is often expressed in imagery of light and darkness: luz, oscuridad, mirar, ciego, ver, saber, conocer.

These chains of words could be extended into a complete glossary of the significant terms that appear in Poemas. The result of Aleixandre's technique is an implicit mode of poetic self-reflection that has not been widely appreciated. In order to demonstrate how this implicit self-consciousness functions in Poemas de la consumación, I have chosen to analyze a representative poem, "Límites y espejo," which, aside from the presence of the word palabras, is not one of the half-dozen or so that explicitly address the question of the poet's language.

The same semantic structure that makes it difficult to interpret a single poem as an independent unit also allows such a poem to be

${ }^{7}$ Carnero distinguishes two modes of knowledge: conocer is a direct and vital discovery of reality in all of its immediacy, whereas saber is the lucidity that results from the loss of this immediacy. Carnero identifies language with saber, and views it in negative terms as an essentially sterile mode of representation (281). 
representative of the larger whole. The opening lines of "Límites y espejo," in the context of the volume as a whole, take on intertextual resonance. The abrupt way in which the poem begins, with a command to an unnamed interlocutor, implies the continuation of a previous dialogue. The enigmatic, aphoristic style and the brevity of the text, similarly, encourage the reader to look for help in the other poems in the book.

I.

No insistas. La juventud no engaña. Brilla a solas.

En un pecho desnudo muere el día.

No son palabras las que a mí me engañan.

Sino el silencio puro que aquí nace.

En tus bordes. La silenciosa línea te limita

pero no te reduce. Oh, tu verdad latiendo aquí en espacios.

The first four lines recombine elements from the beginnings of the poems that immediately precede it in section IV of the book: "La juventud engaña / con veraces palabras" (II: 71)." "Felicidad, no engañas. / Una palabra fue o seria, y dulce / quedó en el labio" (II: 72)." "La juventud no lo conoce, por eso dura, y sigue" (II: 73). These poems, variations on a theme, evoke two semantic networks: language and its deceptiveness, and the contrast between youth and old-age that the majority of critics have seen as the major theme of Aleixandre's later poetry. "Límites y espejo" is a representative poem in Poemas de la consumación because of the way in which it fuses these two preoccupations. My thesis is that Aleixandre views the opposition between youth and old-age in terms of a parallel opposition between reality and its imperfect linguistic representation. Old-age is a pallid reflection of youth, just as language echoes but does not capture what it attempts to represent. The title of the poem, in this case, would suggest the limits of language's mirroring, which has the paradoxical effect of imitating reality while missing the essential truth.

Limits and borders in Aleixandre's poetry almost always have an ambiguous meaning. By definition they circumscribe and delimit. At the same time, to reach the limit is to come into contact with the absolute. The lover in La destrucción o el amor, for example, feels "los hermosos límites de la vida" (I: 331). In the mirror's visual image, the poet attempts to have the benefits of mimesis without 
its drawbacks. He wishes to create a representation that limits without being reductive. The line, by defining the outlines of the image, also gives it its human, mortal dimension, and thus defines its essential truth. The "pure silence" of vision would appear to transcend the inherent deceptiveness of language. The mirror, of course, is a traditional symbol of pure, unmediated mimesis, though it can also represent the dangers of such mimesis, as in the myth of Narcissus. The second-person singular tú in these lines could be seen as a desdoblamiento of the poet. I would interpret this figure, however, as the poet's younger beloved, who appears in other poems of the volume. This female figure would thus stand in contrast to the older poet, who remains trapped within the less perfect medium of language.

The second stanza of "Límites y espejo" links the ambiguity of limits to another, similar paradox having to do with consummation, perfection, and death:

II.

Sólo un cuerpo desnudo enseña bordes.

Quien se limita existe. Tú en la tierra.

Cuán diferente tierra se descoge

y se agrupa y reluce y, suma, enciéndese,

carne o resina, o cuerpo, alto, latiendo,

llameando. Oh, si vivir es consumirse, ¡muere!

Consumación, of course, means "fulfillment, consummation, perfection." In Spanish, however, the word has the secondary meaning of "extinction, death, the end of time." Thus it combines the connotations of two distinct verbs, consumar and consumir. As the flame of life reaches its limits it consumes itself and at the same time reaches its point of consummation. This stanza describes the image of the beloved in the mirror in terms of Aleixandre's view of human life as a momentary state of exception in the universe. The limits are both spatial and temporal: they are the edges of her body, and the time frame that defines her existence as a "different kind of earth," one that only very briefly takes on human form. The brevity of life, its exceptionality in the context of the entire cosmos, is expressed in the virtual simultaneity of birth and death. ${ }^{8}$

${ }^{8}$ Aleixandre anticipates many of the preoccupations of Poemas de la consumación in a set of poems grouped under the rubric "Nacimiento último" and included in the collection of the same name (I: 609-624). 
By emphasizing the shortness of the human life span the poet is able to minimize the possible difference in age between the poet and his beloved: if birth and death occur together, like the beginning and end of a lightning bolt, youth and old-age become practically indistinguishable.

The third and final stanza of the poem returns to the idea of the imperfection of representation, striking a more subdued tone after the exaltation of the second section.

III.

Pero quien muere nace, y aquí aún existes.

¿La misma? No es un espejo un rostro aunque repita su gesto. Quizá su voz. En el espejo hiélase una imagen

de un sonido. ¡Cómo en el vidrio el labio dejó huellas!

El vaho tan sólo de lo que tú amaras.

In contrast to the more optimistic tone of the beginning of the poem, the speaker now emphasizes the inadequacy of representation: a mirror is not the face it reflects. In the first stanza, the essential truth of the woman persists in the illusory three-dimensionality of the mirror's reflection ("Oh tu verdad latiendo aquí en espacios"). Now, however, the mirror freezes the reality that it reflects, converting even the poet's voice into an inert, spatial representation, twice removed from its source. The image of kissing the mirror calls to mind some lines from Pedro Salinas's Presagios:

\footnotetext{
'Bésame', dices. Te beso, y mientras te beso pienso en los fríos que serán tus labios en el espejo (60)
}

The situation in Aleixandre's poem, however, is almost the exact reverse. Instead of kissing the woman while thinking of her reflection in the mirror, as does the speaker in the Salinas poem, Aleixandre's speaker conceives of his erotic encounter through the indirect medium of the mirror image. In the immediacy of the moment Salinas attempts to distance the kiss by converting it into a cold representation of itself. Aleixandre, in contrast, feels the last warmth of a past sexual union in the imprint of his lover's lips on the glass. We should remember that, in the semantic universe of Poemas de la consumación, kissing and speaking are often parallel acts. The poet, at the terminal point in his life, becomes the empty image of what his companion had loved. 
The poem that immediately follows "Límites y espejo" in Poemas de la consumación, "Rostro tras el cristal (Mirada del viejo)," is another variation on the same theme:

O tarde o pronto o nunca.

Pero ahí tras el cristal el rostro insiste.

Junto a unas flores naturales la misma flor se muestra

en forma de color, mejilla, rosa.

Tras el cristal la rosa es siempre rosa.

Pero no huele.

La juventud distante es ella misma.

Pero aquí no se oye.

Sólo la luz traspasa el cristal virgen. (II: 75)

In this case a windowpane takes the place of the mirror. As in "Límites," the poem is structured around the contrast between youth and old-age, sight and sound (and in this case smell), reality and its sensory representation. The poet observes his beloved through a medium that preserves her image in its purified form, while separating him from its vitality. Unlike "Límites y espejo," this poem does not explicitly mention language, "las palabras." Nevertheless, it forms part of Aleixandre's overall meditation on the limits of representation, and thus exhibits the self-reflexivity that characterizes all of the poet's later work.

The term metapoetry usually implies the existence of another kind of poetry, one that does not reflect upon itself. The implicit mode of self-reflection found in Aleixandre's later work, however, subverts any line the critic might wish to draw between metapoetry and other modes of poetic discourse. ${ }^{9}$ The question of poetic language, announced in "Las palabras del poeta," becomes inseparable from the epistemological problem of the relation between reality and its representation, and the vital problem posed by the imminence of old-age and death. In Poemas de la consumación the limits of language come to represent the limits of life itself. Poetic language reflects upon itself in the act of representation, or, more

${ }^{9}$ Theories of poetic self-consciousness are often based on the idea of the subversion of mimesis. It might be argued, however, that mimesis is not a generic norm for lyric poetry in the same way it is for other genres. Unlike prose narration or theater, where the reader might expect to find an illusion of reality, poetry is already an inherently self-reflexive genre, one that rarely claims to be referential. Thus any attempt to distinguish between ordinary poetic discourse and the selfconscious commentary on this discourse will beg the question of what constitutes poetic language in the first place. 
accurately, in the process of failing to represent a more essential reality. This "failure" is the consummate achievement of Aleixandre's later poetry.

Ohio State University, Columbus

\section{WORKS CITED}

Aleixandre, Vicente. Espadas como labios. La destrucción o el amor. José Luis Cano, ed. Madrid: Castalia, 1972.

- Obras completas. 2 Vols. Madrid: Aguilar, 1978

Bousoño, Carlos. La poesía de Vicente Aleixandre. 3rd. ed. Madrid: Gredos, 1977.

Cano, José Luis, ed. Vicente Aleixandre. Madrid: Taurus, 1977.

Carnero, Guillermo. “ 'Conocer' y 'saber' en Poemas de la consumación y Diálogos del conocimiento.” Cano 274-282.

Daydí Tolson, Santiago. Vicente Aleixandre: A Critical Appraisal. Ypsilanti, Michigan: Bilingual Press, 1981.

Gimferrer, Pere. "La poesía última de Vicente Aleixandre." Cano 265-273.

Ilie, Paul. "Descent and Castration." Daydí-Tolson 104-121.

Jakobson, Roman. "Closing Statement on Linguistics and Poetics." Semiotics: An Introductory Anthology. Robert E. Innis, ed. Bloomington: Indiana UP, 1985. 147-175.

Najt, Myriam. "La palabra 'palabra' en 'La palabra del poeta.' " Cuadernos Hispanoamericanos 352-354 (Oct.-Dec. 1979). 581-93.

Novo Villaverde, Yolanda. Daydí-Tolson 122-144.

Paz, Octavio. Corriente alterna. México: Siglo Veintiuno, 1967.

Pope, Randolph D. "Vicente Aleixandre y las limitaciones del lenguaje." DaydíTolson 245-257.

Puccini, Dario. La palabra poética de Vicente Aleixandre. Barcelona: Ariel, 1979.

Salinas, Pedro. Poesías completas. Barcelona: Barral, 1971.

Sherno, Sylvia. R. "The Paradox of Poetry in Blas de Otero's Esto no es un libro." Hispania. 70: 40 (December, 1987): 768-775.

Silver, Philip. La casa de Anteo. Madrid: Taurus, 1985.

Villena, Luis Antonio de. "La luna, astro final del "Primer Aleixandre" (Algo sobre Mundo a solas)." Insula 368-369 (July-August 1977): 8, 33. 